Coding and Redundancy 



\section{Coding and Redundancy}

Man-Made and

Animal-Evolved Signals

Jack P. Hailman

Harvard University Press

Cambridge, Massachusetts, and London, England 2008 
Copyright () 2008 by Jack P. Hailman

All rights reserved

Printed in the United States of America

Library of Congress Cataloging-in-Publication Data

Hailman, Jack Parker, 1936-

Coding and redundancy : man-made and animal-evolved signals /

Jack P. Hailman.

p. $\mathrm{cm}$.

Includes bibliographical references and index.

ISBN 978-0-674-02795-4 (alk. paper)

1. Coding theory. 2. Animal communication-Mathematical models. 3. Information theory. I. Title.

QA268.H34 2008

$003^{\prime} .54-\mathrm{dc} 22 \quad 2007043109$ 
For Peter H. Klopfer

and my other great teachers and mentors:

Philip Teitelbaum, Edward O. Wilson, and in memory of William H. Drury,

Donald R. Griffin, Daniel S. Lebrman, Romeo Mansuetti, Ernst Mayr,

and Raymond A. Paynter Jr. 
